\title{
Effects of Combined Dietary Chromium(III) Propionate Complex and Thiamine Supplementation on Insulin Sensitivity, Blood Biochemical Indices, and Mineral Levels in High-Fructose-Fed Rats
}

\author{
Ewelina Król • Zbigniew Krejpcio • \\ Sławomir Michalak • Rafal W. Wójciak • \\ Paweł Bogdański
}

Received: 23 July 2012 / Accepted: 26 September 2012 / Published online: 16 October 2012

(C) The Author(s) 2012. This article is published with open access at Springerlink.com

\begin{abstract}
Insulin resistance is the first step in glucose intolerance and the development of type 2 diabetes mellitus, thus effective prevention strategies should also include dietary interventions to enhance insulin sensitivity. Nutrients, such as microelement chromium(III) and thiamine, play regulatory roles in carbohydrate metabolism. The objective of this study was to evaluate the insulin-sensitizing potential of the combined supplementary chromium(III) propionate complex (CrProp) and thiamine in insulin resistance animal model (rats fed a high-fructose diet). The experiment was carried out on 40 nine-week-old male Wistar rats divided into five groups (eight animals each). Animals were fed ad
\end{abstract}

E. Król $(\bowtie) \cdot Z$. Krejpcio $\cdot$ R. W. Wójciak

Department of Human Nutrition and Hygiene,

Poznan University of Life Sciences,

31 Wojska Polskiego,

60-624 Poznan, Poland

e-mail: ekrol@up.poznan.pl

S. Michalak

Department of Neurochemistry and Neuropathology,

Poznan University of Medical Sciences,

49 Przybyszewskiego,

60-355 Poznan, Poland

R. W. Wójciak

Department of Clinical Psychology,

Poznan University of Medical Sciences,

70 Bukowska,

60-812 Poznan, Poland

P. Bogdański

Department of Internal Medicine,

Metabolic Disorders and Hypertension,

Poznan University of Medical Sciences,

84 Szamarzewskiego,

60-569 Poznan, Poland libitum: the control diet (AIN-93 M) and high-fructose diets with and without a combination of two levels of CrProp (0.1 and $1 \mathrm{mg} \mathrm{Cr} / \mathrm{kg}$ body mass/day) and two levels of thiamine ( 0.5 and $10 \mathrm{mg} / \mathrm{kg}$ body mass/day) for 8 weeks. At the end of the experiment rats were sacrificed to collect blood and internal organs for analyses of blood biochemical and hematologic indices as well as tissular microelement levels that were measured using appropriate methods. It was found that both supplementary CrProp and thiamine (given alone) have significant insulin-sensitizing and moderate bloodlipid-lowering properties, while the combined supplementation with these agents does not give synergistic effects in insulin-resistant rats. CrProp given separately increased kidney $\mathrm{Cu}$ and $\mathrm{Cr}$ levels, while thiamine alone increased hepatic $\mathrm{Cu}$ contents and decreased renal $\mathrm{Zn}$ and $\mathrm{Cu}$ contents.

Keywords Chromium(III) propionate complex · Thiamine · Supplementation $\cdot$ Insulin resistance $\cdot$ Rats

\section{Introduction}

Major causes of the observed epidemic of obesity include overnutrition, sedentary lifestyles, and a lack of physical activity that bring about serious health problems such as metabolic disorders, insulin resistance, type 2 diabetes, and cardiovascular disease [1]. It is predicted that by the year 2030 over 366 million people worldwide will be afflicted by type 2 diabetes [2]. The insulin resistance, defined as an impaired responsiveness of the body to insulin, is a prediabetic stage associated with obesity, leading to type 2 diabetes [3]. Studies have shown that insulin resistance is observed long before the development of diabetes, thus it 
is believed that early identification and treatment of individuals with prediabetes can delay the progression of fullblown diabetes and related complications [4]. Diet and exercise can to some extent attenuate insulin resistance, but they are often inefficient in bringing about significant improvements. For this reason pharmacological medications (e.g., thiazolinodiones and biguanides) are usually applied. However, these drugs can cause serious side effects. Therefore increasing efforts have been made to search for bioactive compounds from dietary sources that are able to improve insulin action and blood glucose and lipid levels.

Among dietary components involved in glucose metabolism, microelement chromium(III) is considered as a potential agent able to attenuate insulin resistance and its consequences.

Chromium(III) has a documented role in carbohydrate, lipid, and protein metabolism [5]; however, the mechanisms of its action on the molecular level are not fully understood. A recent broad overview of the biological actions of $\mathrm{Cr}$ (III) was excellently presented by Hua et al. [6], therefore, it will not be repeated in this article. In short, many clinical studies [7-9] showed a significant improvement of glucose tolerance after $\mathrm{Cr}$ (III) supplementation in type 2 diabetes. However, there are also other trials that did not confirm a positive effect of Cr(III) supplementation in diabetes [10-12].

Irrespective of controversial scientific opinions, various $\mathrm{Cr}$ (III) compounds (mostly $\mathrm{Cr}$ (III) tris picolinate, $\mathrm{CrPic}$ ) have been advertised, marketed, and used as very popular dietary supplements to decrease body mass gain, improve glycemic control, or reduce appetite. However, the results of a recent model study performed on rats raised some doubts on the essentiality of $\mathrm{Cr}$ for mammals [13].

If $\mathrm{Cr}$ (III) is not an essential element for mammals, but at certain dosages improves impaired glucose and lipid homeostasis, its action could be called "pharmacological" at best [14].

Thiamine is another nutritional factor of interest in the context of glucose metabolism and insulin action. This vitamin is a coenzyme for transketolase, pyruvate dehydrogenase, and the alpha-ketoglutrate dehydrogenase complex [15]; it affects blood glucose level by the hexosamine pathway [16], prevents hyperglycemia by reduction of cell replication and proliferation, and decreases the production of advanced glycation end products [17]. Another mechanism, by which administration of thiamine $(\mathrm{T})$ or its derivates can influence carbohydrates metabolism, is improving the pentose phosphate pathway [18]. Mutation of the thiamine transporter SLC19A2 gene located on chromosome 1q32 is associated with diabetes mellitus, sensorineural deafness, and megaloblastosis $[19,20]$. A low plasma thiamine concentration was observed in types 1 and 2 diabetic patients, and this parameter was also proposed to be a marker of microvascular diabetic complications [21]. Evidence from experimental and clinical studies suggests that metabolism and clearance of thiamine is disturbed in diabetes, leading to tissue-specific thiamine deficiency in the kidney and other sites of development of vascular complications.

Kohda et al. [22] investigated the mechanism of diabetesinduced pyruvate dehydrogenase (PDH) inhibition, and the effect of thiamine in both in vivo and in vitro experiments. Treatment of rats with thiamine significantly, although partially, recovered streptozotocin (STZ)-induced reductions in mitochondrial PDH activity.

Recently, Pacal et al. [23] revealed the role of thiamine status and genetic variability in transketolase and other pentose phosphate cycle enzymes in the progression of diabetic nephropathy in a group of 240 diabetic subjects. The results supported the role of 'functional' thiamine deficiency in the development of hyperglycemia-related pathology.

Thiamine supplementation prevented the development of early-stage nephropathy in diabetic rats and reversed increased urinary albumin excretion in patients with type 2 diabetes and microalbuminuria in two recent clinical trials [24]. In animal models of type 1 (streptozotocin-injected) and type 2 diabetes (leptin-receptor mutant mice) benfotiamine prevented cardiomyopathy [25].

As it was shortly presented above, the mechanisms of $\mathrm{Cr}$ (III) and thiamine action in glucose metabolism are surely different. In our previous study [26], we provided evidence that supplementary chromium(III) propionate complex (CrProp), given in dosages of 1 and $5 \mathrm{mg} / \mathrm{kg}$ body mass/ day for 8 weeks, is able to ameliorate insulin resistance symptoms in high-fructose fed Wistar rats.

In this study, using the insulin resistance animal model (rats fed high-fructose diet), we tested the hypothesis whether the combined administration of these agents could increase the efficacy of insulin action and whether a synergistic effect may occur.

\section{Materials and Methods}

\section{Animals and Diets}

Nine-week-old 40 male Wistar rats were purchased at the Licensed Laboratory Animals Breeding Center (Poznan, Poland). Animals were housed at constant temperature $\left(21 \pm 2{ }^{\circ} \mathrm{C}\right)$, humidity $(55-60 \%)$ and with a $12 \mathrm{~h} / 12 \mathrm{~h}$ day/ night cycle. After 5 days of adaptation period animals were divided into five groups of eight rats each, and kept individually in semi-metabolic cages. Diets used in the experiment were composed, according to the AIN-93 M recommendations [27] (Table 1). The high-fructose diets were obtained from the basal AIN-93 diet, by replacement of wheat starch with fructose (up to $60 \%$ ). Animals were fed ad libitum: the control diet (AIN-93 M) and highfructose diets (HF) with variable levels of $\mathrm{Cr}$ (III) (as the 
Table 1 Composition of diets used in experiment

${ }^{\mathrm{a}} \mathrm{CrProp}$ was added to mineral $\operatorname{mix}$

${ }^{\mathrm{b}}$ Thiamine hydrochloride was added to vitamin mix

\begin{tabular}{|c|c|c|c|c|c|}
\hline \multirow[t]{2}{*}{ Ingredients } & \multicolumn{5}{|l|}{ Diet } \\
\hline & $\begin{array}{l}\text { Control } \\
\text { (C) }\end{array}$ & $\begin{array}{l}\text { High } \\
\text { fructose } \\
(\mathrm{HF})\end{array}$ & $\begin{array}{l}\text { High fructose }+ \\
\mathrm{Cr}(\mathrm{HF}+\mathrm{Cr})\end{array}$ & $\begin{array}{l}\text { High fructose }+ \\
\text { thiamine } \\
(\mathrm{HF}+\mathrm{T})\end{array}$ & $\begin{array}{l}\text { High fructose }+ \\
\text { thiamine }+\mathrm{Cr} \\
(\mathrm{HF}+\mathrm{T}+\mathrm{Cr})\end{array}$ \\
\hline Casein $(\mathrm{g} / \mathrm{kg})$ & 200 & 200 & 200 & 200 & 200 \\
\hline Soybean oil (g/kg) & 70 & 70 & 70 & 70 & 100 \\
\hline Wheat starch $(\mathrm{g} / \mathrm{kg})$ & 535 & 35 & 35 & 35 & 35 \\
\hline Fructose (g/kg) & 0 & 600 & 600 & 600 & 600 \\
\hline Sucrose $(\mathrm{g} / \mathrm{kg})$ & 100 & 0 & 0 & 0 & 0 \\
\hline Potato starch $(\mathrm{g} / \mathrm{kg})$ & 50 & 50 & 50 & 50 & 50 \\
\hline Vitamin mix (g/kg) & 10 & 10 & 10 & 10 & 10 \\
\hline Mineral mix (g/kg) & 35 & 35 & 35 & 35 & 35 \\
\hline $\mathrm{Cr}^{\mathrm{a}}(\mathrm{mg} / \mathrm{kg})$ & 1 & 1 & 10 & 1 & 10 \\
\hline Thiamine $^{\mathrm{b}}(\mathrm{mg} / \mathrm{kg})$ & 5 & 5 & 5 & 100 & 100 \\
\hline
\end{tabular}

chromium(III) propionate complex and thiamine: $\mathrm{HF}$ ( $\mathrm{Cr}$ and $\mathrm{T}$ adequate, 1 and $5 \mathrm{mg} / \mathrm{kg}$ diet, respectively; equals to $0.1 \mathrm{mg} \mathrm{Cr}$ and $0.5 \mathrm{mg} \mathrm{T} / \mathrm{kg}$ body mass per day, respectively), $\mathrm{HF}+\mathrm{Cr}$ (supplemented with $10 \mathrm{mg} \mathrm{Cr} / \mathrm{kg}$ diet, equals to $1 \mathrm{mg} \mathrm{Cr} / \mathrm{kg}$ body mass per day), $\mathrm{HF}+\mathrm{T}$ (supplemented with $\mathrm{T} 100 \mathrm{mg} / \mathrm{kg}$ diet, equals to $10 \mathrm{mg} / \mathrm{kg}$ body mass per day) and $\mathrm{HF}+\mathrm{T}+\mathrm{Cr}$ (supplemented with $\mathrm{Cr}$ and $\mathrm{T}, 10$ and $100 \mathrm{mg} / \mathrm{kg}$ diet; equals to 1 and $10 \mathrm{mg} / \mathrm{kg}$ body mass per day) for 8 weeks.

Food intake was monitored daily and body mass gain weekly.

\section{Test Chemicals}

Thiamine hydrochloride was purchased from SigmaAldrich (USA), while $\mathrm{Cr}$ (III) propionate cation (CrProp) in the form of nitrate salt (chemical formula $\left[\mathrm{Cr}_{3} \mathrm{O}\right.$ $\left.\left(\mathrm{O}_{2} \mathrm{CCH}_{2} \mathrm{CH}_{3}\right)_{6}\left(\mathrm{H}_{2} \mathrm{O}\right)_{3}\right]^{+}\left(\mathrm{NO}_{3}\right)$ was synthesized at the laboratory of the Department of Product Ecology, the Poznan University of Economics, according to the method described previously by Earnshaw et al. [28]. The content of elemental $\mathrm{Cr}$ was $21.5 \%$ and it has been determined by the AAS method (spectrometer AAS-3 with BC correction, Zeiss, Germany).

\section{Data Collection}

At the end of the experiment, after $16 \mathrm{~h}$ fasting, rats were anesthetized with an intraperitoneal thiopental injection (40 mg/kg body mass) and blood for biochemical tests was collected from the aorta to test tubes containing heparin as a coagulant. Additionally, inner organs (liver, kidneys, heart, spleen, pancreas, and testes) were removed for appropriate biochemical tests. Organs were washed in saline, weighed, and stored at $-20{ }^{\circ} \mathrm{C}$ until analyzed. All the procedures used in this study were approved by the Animal Bioethics Committee of Poznan, Poland (Approval \# 37/2007).

Laboratory Analyses

\section{Blood Biochemistry}

The laboratory methods used to determine blood serum indices: glucose, total LDL and HDL cholesterols; triacylglycerols; activity of ALT and AST enzymes; and total protein, urea, and creatinine levels were described previously [26]. Plasma insulin concentration was measured by the RIA method using a kit specific for rats (Linco Research, St. Charles, MO, USA), while tumor necrosis factor alpha $(\mathrm{TNF}-\alpha)$ and interleukin-2 (IL-2) levels by ELISA kits (R\&D Systems, USA). Total antioxidant status (TAS) was assessed spectrophotometrically using a commercial kit (Randox, UK).

Erythrocyte transketolase (ETK) activity and the effect of adding thiamine pyrophosphate (\% TPP effect) were measured by method described previously [29].

The efficacy of insulin resistance was characterized by the homeostasis model assessment (HOMA) indices [30].

HOMA - IR $=$

(Fasting Glucose $\left[\mathrm{mmol} / \mathrm{dm}^{3}\right] \times$ Fasting Insulin $\left.\left[\mathrm{mIU} / \mathrm{dm}^{3}\right]\right) / 22.5$

\section{Microelement Determinations}

Prior to analysis the rats' tissues were digested in $65 \%$ $(w / w)$ spectra pure $\mathrm{HNO}_{3}$ (Merck) in the Microwave Digestion System (MARS 5, CEM). Thereafter, the concentrations of $\mathrm{Fe}, \mathrm{Zn}$, and $\mathrm{Cu}$ in the mineral solutions were measured by the flame-AAS method (spectrometer AAS-3, Zeiss, with 
$\mathrm{BC}$, Germany), while the content of $\mathrm{Cr}$ was determined by the graphite furnace AAS method (spectrometer AA EA 5, with BC, Jenoptic, Germany).

The accuracy of quantitative determinations of $\mathrm{Fe}, \mathrm{Zn}$, $\mathrm{Cu}$, and $\mathrm{Cr}$ was confirmed by a simultaneous analysis of the certified reference material (Pig Kidney BCR ${ }^{\circledR}$ No. 186, Brussels, fortified with the Cr standard).

\section{Statistical Analysis}

All results are presented as means \pm standard deviation. Significance of differences in means were calculated using the oneway ANOVA and Tukey's test. Means were considered statistically different at $p<0.05$. Main and interaction effects of experimental factors ( $\mathrm{Cr}(\mathrm{III})$ and thiamine) were determined by two-way analysis of variance. All calculations were made using the STATISTICA (ver. 7.0) program (StatSoft, Inc. Tulsa).

\section{Results}

The present study is first to our knowledge that evaluates the combined effects of supplementary CrProp and thiamine on insulin resistance and related blood parameters, as well as tissular microelement levels in the insulin-resistant rat model (induced by a high-fructose diet).

In a previous article [26] the effects of supplementary CrProp on carbohydrate and lipid metabolism in the insulin resistance rat model was presented. Some of those results are referenced in this study.

The effects of a high-fructose diet as well as supplementary Cr(III)Prop ( 0.1 and $1 \mathrm{mg} / \mathrm{kg}$ body mass/day) and thiamine $(0.5$ and $10 \mathrm{mg} / \mathrm{kg}$ body mass/day) on overall nutritional indices of rats fed high-fructose diet were presented on Fig. 1 and Table 2.
As it can be seen on Fig. 1, the high-fructose diet tended to decrease relative body mass gain in rats in comparison to the control group; however, due to the variability of individual responses no significant differences were observed. Neither supplementary CrProp nor thiamine (alone and combined) influenced food intake or overall nutritional outcomes in rats (Table 2).

High-fructose feeding, as expected, induced insulin resistance and related blood indices, such as increased serum insulin level, the HOMA-IR index, and serum triacylglycerol concentration by 188,240 , and $63 \%$, respectively. However, it did not influence parameters of oxidative stress (TAS) or inflammation biomarkers (TNF- $\alpha$ and IL-2) (Table 3). Both supplementary CrProp and thiamine significantly attenuated insulin resistance biomarkers in rats fed the HF diet. Additionally, erythrocyte transketolase activity, that is often used as a biomarker of thiamine status, was significantly increased in the HF group (by $41 \%$ ), only slightly in the $\mathrm{HF}+\mathrm{T}$ group (by $31 \%$ ), while surprisingly enough, it was decreased in the $\mathrm{HF}+\mathrm{Cr}$ group (by $32 \%$ ).

The results of two-way analysis of variance are presented in Table 6. As it can be seen, only supplementary CrProp (1 mg $\mathrm{Cr} / \mathrm{kg}$ body mass/day) had a small, but significant blood glucose lowering effect (by $9 \%$ ). Both supplementary CrProp and thiamine (independently) decreased blood insulin concentration (by 27 and $28 \%$, respectively), the HOMA-IR index (by 36 and $40 \%$ ), and triacylglycerol concentration (by 36 and $19 \%$ ).

As it could be expected, supplementary thiamine $(10 \mathrm{mg} / \mathrm{kg}$ body mass/day) significantly increased blood ETK activity (by $40 \%$ ). Surprisingly enough, supplementary CrProp decreased ETK activity (by $30 \%$ ).

Since insulin resistance is a metabolic state linked with an increased oxidative stress and inflammation, serum total antioxidative status and serum interleukin IL-2 concentration were measured. It was found that serum TAS was significantly
Fig. 1 Body mass gain expressed in percentage of initial body mass during experimental period

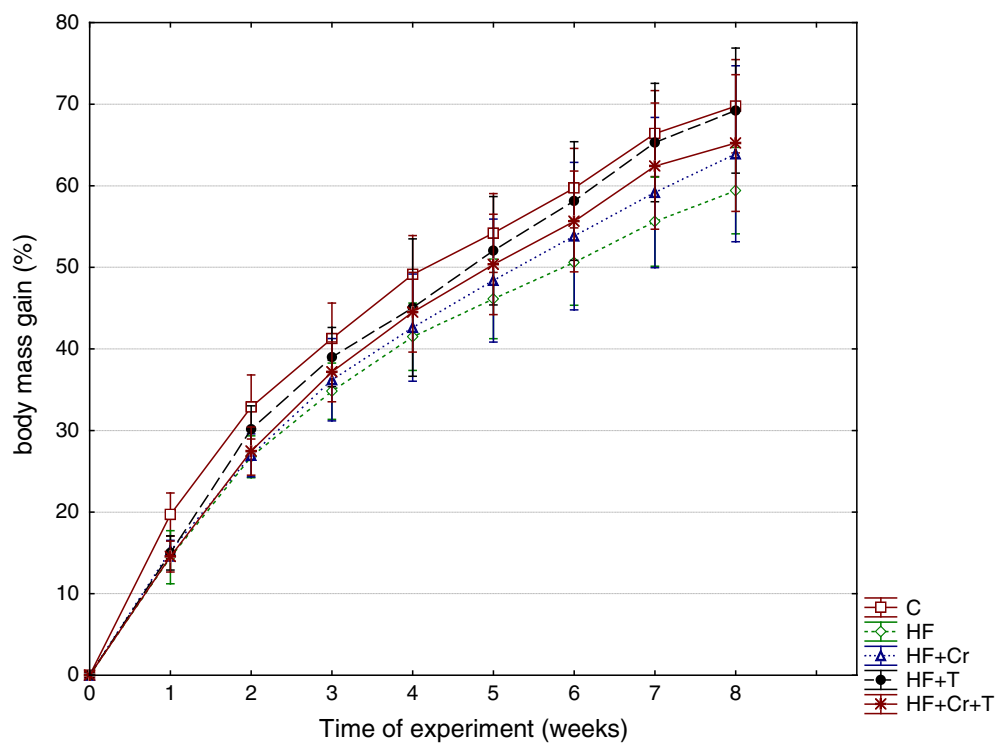


Table 2 Effect of $\mathrm{Cr}(\mathrm{III})$, thiamine, and thiamine combined with $\mathrm{Cr}(\mathrm{III})$ overall growth indices in rats

\begin{tabular}{|c|c|c|c|c|c|}
\hline \multirow[t]{2}{*}{ Index } & \multicolumn{5}{|c|}{ Experimental group } \\
\hline & $\mathrm{C}$ & $\mathrm{HF}$ & $\mathrm{HF}+\mathrm{T}$ & $\mathrm{HF}+\mathrm{Cr}$ & $\mathrm{HF}+\mathrm{T}+\mathrm{Cr}$ \\
\hline Food intake (g/day) & $18.49 \pm 0.63$ & $19.95 \pm 0.63$ & $20.82 \pm 0.88$ & $20.60 \pm 1.39$ & $20.45 \pm 1.49$ \\
\hline Relative body weight gain (\%) & $69.21 \pm 5.12$ & $59.25 \pm 5.89$ & $63.06 \pm 7.63$ & $67.94 \pm 8.81$ & $62.42 \pm 8.14$ \\
\hline Body mass/body length ratio (g/cm) & $14.26 \pm 0.53$ & $14.65 \pm 0.78$ & $15.62 \pm 0.85$ & $15.44 \pm 0.25$ & $15.24 \pm 0.95$ \\
\hline
\end{tabular}

$C$ group fed control diet, $H F$ group fed high-fructose diet, $H F+C r$ group fed high-fructose diet supplemented with $\mathrm{Cr}(\mathrm{III}), H F+T$ group fed highfructose diet supplemented with thiamine, $\mathrm{HF}+\mathrm{Cr}+\mathrm{T}$ group fed high-fructose diet supplemented with $\mathrm{Cr}(\mathrm{III})$ and thiamine

decreased (by $13 \%$ ) only by supplementary thiamine. No interaction effects of experimental factors were observed for these indices.

These results indicate that both supplementary CrProp and thiamine can improve insulin action and glucose utilization independently, but no synergistic effects occur during co-administration of these agents.

In the case of a prolonged drug or supplementary treatment in diabetes or any other diseases, it is necessary to consider possible adverse effects. Thiamine is a water-soluble vitamin, practically non-toxic. There are no reports available on adverse effects from consumption of excess thiamine by ingestion of food and supplements. So far no tolerable upper intake level (UL) was established for thiamine.

Although $\mathrm{Cr}$ (III) compounds are rather of low acute toxicity, in some cases excessive dosages can do harm in various organs and systems [31]. For this reason it is necessary to monitor biomarkers of general toxicity. As can be seen in Table 4, neither HF diet nor supplementary CrProp and thiamine affected toxicity parameters in rats, except serum ALT level, that was significantly increased (by $27 \%$ ), while both supplements attenuated these changes. An interaction effect for serum ALT level was observed. When $\mathrm{Cr}$ was given at adequate levels with supplementary thiamine it decreased serum ALT activity.

Supplementary minerals and vitamins given in excessive dosages can affect mineral status. The effects of high-fructose diet and supplementary CrProp and thiamine on tissular Fe, $\mathrm{Zn}, \mathrm{Cu}$, and $\mathrm{Cr}$ levels are presented in Table 5. The highfructose diet slightly increased liver Fe content and significantly decreased liver $\mathrm{Cu}$ level (by $13 \%$ ). Supplementary CrProp and thiamine (given separately) decreased liver $\mathrm{Fe}$ (both by $25 \%$ ), while the combined administration of these compounds normalized liver $\mathrm{Fe}$ in rats. On the other hand, supplementary CrProp and thiamine (both separately and combined) normalized liver $\mathrm{Cr}$ level in rats.

The high-fructose diet did not induce significant changes in kidney microelement concentrations.

Supplementary CrProp, as expected, brought about an increase of kidney $\mathrm{Cr}$ level (by $47 \%$ ), but it did not affect

Table 3 Effect of $\mathrm{Cr}(\mathrm{III})$, thiamine, and thiamine combined with $\mathrm{Cr}(\mathrm{III})$ supplementation on biochemical indices of rats (mean $\pm \mathrm{SD}$ )

\begin{tabular}{|c|c|c|c|c|c|}
\hline \multirow[t]{2}{*}{ Parameter } & \multicolumn{5}{|c|}{ Experimental group } \\
\hline & $\mathrm{C}$ & $\mathrm{HF}$ & $\mathrm{HF}+\mathrm{T}$ & $\mathrm{HF}+\mathrm{Cr}$ & $\mathrm{HF}+\mathrm{T}+\mathrm{Cr}$ \\
\hline Glucose concentration $\left(\mathrm{mmol} / \mathrm{dm}^{3}\right)$ & $6.34 \pm 0.58^{\mathrm{ab}}$ & $7.38 \pm 0.75^{\mathrm{b}}$ & $7.17 \pm 0.57^{\mathrm{b}}$ & $6.95 \pm 0.89^{\mathrm{ab}}$ & $6.17 \pm 0.61^{\mathrm{a}}$ \\
\hline Insulin concentration $\left(\mathrm{mIU} / \mathrm{dm}^{3}\right)$ & $18.74 \pm 7.25^{\mathrm{a}}$ & $53.23 \pm 14.52^{\mathrm{b}}$ & $29.59 \pm 14.47^{\mathrm{ab}}$ & $32.03 \pm 9.51^{\mathrm{ab}}$ & $27.1 \pm 11.1^{\mathrm{a}}$ \\
\hline HOMA-IR index & $5.28 \pm 1.96^{\mathrm{a}}$ & $17.46 \pm 5.03^{\mathrm{b}}$ & $9.51 \pm 3.12^{\mathrm{ab}}$ & $10.13 \pm 3.64^{\mathrm{a}}$ & $7.28 \pm 3.30^{\mathrm{a}}$ \\
\hline Total cholesterol concentration $\left(\mathrm{mmol} / \mathrm{dm}^{3}\right)$ & $2.12 \pm 0.21$ & $2.47 \pm 0.30$ & $2.30 \pm 0.31$ & $2.25 \pm 0.21$ & $2.31 \pm 0.36$ \\
\hline HDL cholesterol concentration $\left(\mathrm{mmol} / \mathrm{dm}^{3}\right)$ & $1.44 \pm 0.15$ & $1.63 \pm 0.19$ & $1.48 \pm 0.18$ & $1.58 \pm 0.21$ & $1.62 \pm 0.22$ \\
\hline LDL cholesterol concentration $\left(\mathrm{mmol} / \mathrm{dm}^{3}\right)$ & $0.49 \pm 0.08$ & $0.58 \pm 0.13$ & $0.44 \pm 0.09$ & $0.52 \pm 0.13$ & $0.47 \pm 0.08$ \\
\hline Triacylglycerols concentration $\left(\mathrm{mmol} / \mathrm{dm}^{3}\right)$ & $0.35 \pm 0.14^{\mathrm{ab}}$ & $0.58 \pm 0.13^{\mathrm{b}}$ & $0.53 \pm 0.21^{\mathrm{ab}}$ & $0.50 \pm 0.15^{\mathrm{ab}}$ & $0.33 \pm 0.05^{\mathrm{a}}$ \\
\hline $\operatorname{TAS}\left(\mathrm{mmol} / \mathrm{dm}^{3}\right)$ & $0.93 \pm 0.12$ & $1.03 \pm 0.16$ & $0.86 \pm 0.03$ & $1.01 \pm 0.09$ & $0.92 \pm 0.09$ \\
\hline TNF- $\alpha\left(\mathrm{ng} / \mathrm{dm}^{3}\right)$ & $167 \pm 18$ & $163 \pm 27$ & $165 \pm 14$ & $159 \pm 25$ & $159 \pm 12$ \\
\hline IL-2 (ng/dm³) & $374 \pm 22$ & $397 \pm 48$ & $354 \pm 44$ & $352 \pm 32$ & $363 \pm 45$ \\
\hline Erythocytes transketolase activity (U/g Hb) & $0.81 \pm 0.33^{\mathrm{ab}}$ & $1.14 \pm 0.24^{\mathrm{b}}$ & $1.06 \pm 0.26^{\mathrm{b}}$ & $0.55 \pm 0.24^{\mathrm{a}}$ & $0.98 \pm 0.26^{\mathrm{ab}}$ \\
\hline
\end{tabular}

Each value is expressed as mean \pm standard deviation for eight rats per experimental group. Values in the row without common superscripts differ significantly at $p<0.05$

$C$ group fed control diet, $H F$ group fed high-fructose diet, $H F+C r$ group fed high-fructose diet supplemented with $\mathrm{Cr}(\mathrm{III}), H F+T$ group fed highfructose diet supplemented with thiamine, $\mathrm{HF}+\mathrm{Cr}+\mathrm{T}$ group fed high-fructose diet supplemented with $\mathrm{Cr}(\mathrm{III})$ and thiamine 
Table 4 Effect of $\mathrm{Cr}(\mathrm{III})$, thiamine, and thiamine combined with $\mathrm{Cr}(\mathrm{III})$ supplementation on general toxicity indices of rats (mean $\pm \mathrm{SD}$ )

\begin{tabular}{lcrrrr}
\hline Blood index & \multicolumn{2}{l}{ Experimental group } & & & \\
\cline { 2 - 6 } & $\mathrm{C}$ & $\mathrm{HF}$ & $\mathrm{HF}+\mathrm{T}$ & $\mathrm{HF}+\mathrm{Cr}$ & $\mathrm{HF}+\mathrm{T}+\mathrm{Cr}$ \\
\hline ALT $\left(\mathrm{U} / \mathrm{dm}^{3}\right)$ & $22.73 \pm 3.25^{\mathrm{a}}$ & $28.71 \pm 3.20^{\mathrm{b}}$ & $23.71 \pm 3.09^{\mathrm{a}}$ & $21.88 \pm 2.75^{\mathrm{a}}$ & $25.00 \pm 3.16^{\mathrm{ab}}$ \\
AST $\left(\mathrm{U} / \mathrm{dm}^{3}\right)$ & $108.71 \pm 13.15$ & $114.07 \pm 16.15$ & $105.43 \pm 7.23$ & $106.3 \pm 10.4$ & $111.29 \pm 11.40$ \\
Total protein $\left(10^{-2} \mathrm{~kg}^{\mathrm{a}} \mathrm{dm}^{3}\right)$ & $5.87 \pm 0.14$ & $5.98 \pm 0.22$ & $6.03 \pm 0.25$ & $6.03 \pm 0.18$ & $6.01 \pm 0.20$ \\
Creatinine $\left(\mu \mathrm{mol} / \mathrm{dm}^{3}\right)$ & $36.39 \pm 3.54$ & $37.09 \pm 3.51$ & $36.24 \pm 3.54$ & $33.64 \pm 3.54$ & $35.36 \pm 5.31$ \\
Urea $\left(\mathrm{mmol} / \mathrm{dm}^{3}\right)$ & $5.32 \pm 0.64$ & $5.01 \pm 0.90$ & $5.42 \pm 0.76$ & $5.39 \pm 1.04$ & $5.26 \pm 0.46$ \\
\hline
\end{tabular}

Each value is expressed as mean \pm standard deviation for eight rats per experimental group. Values in the row without common superscripts differ significantly at $p<0.05$

$C$ group fed control diet, $H F$ group fed high-fructose diet, $H F+C r$ group fed high-fructose diet supplemented with $\mathrm{Cr}(\mathrm{III}), H F+T$ group fed highfructose diet supplemented with thiamine, $\mathrm{HF}+\mathrm{Cr}+\mathrm{T}$ group fed high-fructose diet supplemented with $\mathrm{Cr}$ (III) and thiamine

tissular Fe and Zn status in rats. Supplementary thiamine markedly decreased kidney $\mathrm{Cu}$ content.

Analysis of variance showed that supplementary CrProp significantly elevated kidney $\mathrm{Cu}$ and $\mathrm{Cr}$ levels (by 10 and $47 \%$, respectively), while supplementary thiamine markedly increased liver $\mathrm{Cu}$ content (by $11 \%$ ), whereas it decreased kidney $\mathrm{Zn}$ and $\mathrm{Cu}$ concentrations (by 7 and $13 \%$, respectively; Table 6).

Besides, interaction effects were observed for liver Fe and $\mathrm{Cu}$ levels. When $\mathrm{Cr}$ was given at adequate levels with supplementary thiamine it decreased liver Fe level, while increased liver $\mathrm{Cu}$ content.

\section{Discussion}

Insulin resistance preceded by inflammation increases the risk of diabetes, hypertension, and cardiovascular diseases.
A decreased insulin sensitivity manifests itself in a reduced insulin-stimulated glucose uptake, reduced insulinsuppression of endogenous glucose production, reduced antilipolysis, decreased insulin-induced vasodilation, dyslipidemia, and platelet hyperaggregability [32]. Additionally, decreased insulin sensitivity, due to the interruption in the biological rhythm of the key metabolic pathways, affects food intake control, digestion, transport, and absorption of nutrients [33].

Various $\mathrm{Cr}$ (III) compounds as dietary supplements and therapeutic agents have been studied extensively for their insulin sensitizing, glucose and lipid lowering, and antidiabetic potential in animal models and diabetic patients in the last decades. The most studied compound for this purpose was $\mathrm{Cr}$ tris picolinate (CrPic), although giving inconsistent results. Another promising form of $\mathrm{Cr}$ is CrProp, introduced by Vincent and co-workers [34-39].

Table 5 The contents of $\mathrm{Fe}, \mathrm{Zn}, \mathrm{Cu}$, and $\mathrm{Cr}$ in liver and kidney of rats

\begin{tabular}{|c|c|c|c|c|c|}
\hline \multirow[t]{2}{*}{ Index } & \multicolumn{5}{|c|}{ Experimental group } \\
\hline & $\mathrm{C}$ & $\mathrm{HF}$ & $\mathrm{HF}+\mathrm{T}$ & $\mathrm{HF}+\mathrm{Cr}$ & $\mathrm{HF}+\mathrm{T}+\mathrm{Cr}$ \\
\hline \multicolumn{6}{|c|}{ Liver ( $\mu \mathrm{g} / \mathrm{g}$ d.m.) } \\
\hline $\mathrm{Fe}$ & $317 \pm 41^{\mathrm{b}}$ & $353 \pm 46^{\mathrm{b}}$ & $263 \pm 23^{\mathrm{a}}$ & $264 \pm 50^{\mathrm{a}}$ & $307 \pm 53^{\mathrm{ab}}$ \\
\hline $\mathrm{Zn}$ & $100.1 \pm 8.1$ & $103.4 \pm 9.6$ & $94.8 \pm 5.4$ & $101.3 \pm 8.1$ & $96.5 \pm 14.3$ \\
\hline $\mathrm{Cu}$ & $22.8 \pm 2.4^{\mathrm{b}}$ & $19.7 \pm 2.5^{\mathrm{a}}$ & $23.8 \pm 2.3^{\mathrm{b}}$ & $21.7 \pm 1.8^{\mathrm{ab}}$ & $21.1 \pm 2.5^{\mathrm{ab}}$ \\
\hline $\mathrm{Cr}$ & $0.52 \pm 0.09$ & $0.48 \pm 0.08$ & $0.51 \pm 0.12$ & $0.61 \pm 0.16$ & $0.62 \pm 0.09$ \\
\hline \multicolumn{6}{|c|}{ Kidney ( $\mu \mathrm{g} / \mathrm{g}$ d.m.) } \\
\hline $\mathrm{Fe}$ & $345.9 \pm 33$ & $322.0 \pm 32$ & $339.3 \pm 36$ & $305.0 \pm 18$ & $329.3 \pm 53$ \\
\hline $\mathrm{Zn}$ & $82.4 \pm 7.1$ & $83.0 \pm 7.5$ & $74.7 \pm 4.6$ & $82.24 \pm 6.86$ & $76.2 \pm 6.3$ \\
\hline $\mathrm{Cu}$ & $39.6 \pm 6.3^{\mathrm{b}}$ & $35.5 \pm 6.4^{\mathrm{ab}}$ & $32.5 \pm 6.6^{\mathrm{a}}$ & $38.84 \pm 8.12^{\mathrm{b}}$ & $33.1 \pm 2.5^{\mathrm{a}}$ \\
\hline $\mathrm{Cr}$ & $0.56 \pm 0.15^{\mathrm{a}}$ & $0.56 \pm 0.17^{\mathrm{a}}$ & $0.57 \pm 0.12^{\mathrm{a}}$ & $0.84 \pm 0.08^{\mathrm{b}}$ & $0.83 \pm 0.16^{\mathrm{b}}$ \\
\hline
\end{tabular}

Each value is expressed as mean \pm standard deviation for eight rats per experimental group. Values in the row without common superscripts differ significantly at $p<0.05$

$C$ group fed control diet, $H F$ group fed high-fructose diet, $H F+C r$ group fed high-fructose diet supplemented with $\mathrm{Cr}(\mathrm{III}), H F+T$ group fed highfructose diet supplemented with thiamine, $\mathrm{HF}+\mathrm{Cr}+\mathrm{T}$ group fed high-fructose diet supplemented with $\mathrm{Cr}(\mathrm{III})$ and thiamine 
Table 6 Main and interaction effects of supplementation with thiamine and CrProp in rats fed high-fructose diets
Only parameters for which significant effects were detected are presented

$* p<0.05 ; * * p<0.01 ; * * * p<$ 0.001 (statistically significant differences)

\begin{tabular}{|c|c|c|c|}
\hline \multirow[t]{2}{*}{ Index } & \multicolumn{2}{|l|}{ Main effects } & \multirow{2}{*}{$\begin{array}{l}\text { Interaction } \\
\text { effects } \\
\mathrm{Cr} \times \text { thiamine } \mathrm{r}\end{array}$} \\
\hline & $\begin{array}{l}\text { Cr level } \\
\text { (mg/kg b.w./day) } \\
0.1 \text { vs } 1.0\end{array}$ & $\begin{array}{l}\text { Thiamine level } \\
\text { (mg/kg b.w/.day) } \\
0.5 \text { vs } 10\end{array}$ & \\
\hline $\begin{array}{l}\text { Glucose concentration } \\
\left(\mathrm{mmol} / \mathrm{dm}^{3}\right)\end{array}$ & $\begin{array}{l}7.21 \pm 0.7 \\
6.56 \pm 0.7^{*}\end{array}$ & $\begin{array}{l}7.13 \pm 0.7 \\
6.71 \pm 0.8\end{array}$ & NS \\
\hline $\begin{array}{l}\text { Insulin concentration } \\
\left(\mathrm{mIU} / \mathrm{dm}^{3}\right)\end{array}$ & $\begin{array}{l}41.3 \pm 23.6 \\
30.2 \pm 10.3^{*}\end{array}$ & $\begin{array}{l}39.7 \pm 19.8 \\
28.3 \pm 12.1^{*}\end{array}$ & NS \\
\hline HOMA-IR index & $\begin{array}{l}13.7 \pm 4.39 \\
8.71 \pm 3.97^{*}\end{array}$ & $\begin{array}{l}14.0 \pm 4.45 \\
8.39 \pm 3.21^{*}\end{array}$ & NS \\
\hline $\begin{array}{l}\text { Triacylglycerols concentration } \\
\left(\mathrm{mmol} / \mathrm{dm}^{3}\right)\end{array}$ & $\begin{array}{l}0.55 \pm 0.16 \\
0.43 \pm 0.11^{*}\end{array}$ & $\begin{array}{l}0.53 \pm 0.11 \\
0.43 \pm 0.18^{*}\end{array}$ & NS \\
\hline $\begin{array}{l}\text { Erythocytes transketolase activity } \\
(\mathrm{U} / \mathrm{g} \mathrm{Hb})\end{array}$ & $\begin{array}{l}1.09 \pm 0.37 \\
0.76 \pm 0.36^{*}\end{array}$ & $\begin{array}{l}0.77 \pm 0.38 \\
1.08 \pm 0.39^{*}\end{array}$ & NS \\
\hline $\begin{array}{l}\text { ALT } \\
\left(\mathrm{U} / \mathrm{dm}^{3}\right)\end{array}$ & $\begin{array}{l}26.2 \pm 3.9 \\
23.3 \pm 3.3^{*}\end{array}$ & $\begin{array}{l}25.1 \pm 4.5 \\
24.4 \pm 3.1\end{array}$ & $* *$ \\
\hline $\begin{array}{l}\text { TAS } \\
\left(\mathrm{mmol} / \mathrm{dm}^{3}\right)\end{array}$ & $\begin{array}{l}0.95 \pm 0.14 \\
0.97 \pm 0.10\end{array}$ & $\begin{array}{l}1.02 \pm 0.12 \\
0.89 \pm 0.07^{*}\end{array}$ & NS \\
\hline $\begin{array}{l}\text { Liver Fe } \\
(\mu \mathrm{g} / \mathrm{g} \text { d.m. })\end{array}$ & $\begin{array}{l}305 \pm 59.7 \\
286 \pm 54.3\end{array}$ & $\begin{array}{l}305 \pm 67.2 \\
285 \pm 45.4\end{array}$ & $* * *$ \\
\hline $\begin{array}{l}\text { Liver } \mathrm{Cu} \\
(\mu \mathrm{g} / \mathrm{g} \text { d.m. })\end{array}$ & $\begin{array}{l}21.8 \pm 3.27 \\
21.0 \pm 2.56\end{array}$ & $\begin{array}{l}20.3 \pm 2.8 \\
22.5 \pm 2.7^{*}\end{array}$ & $*$ \\
\hline $\begin{array}{l}\text { Kidney Zn } \\
(\mu \mathrm{g} / \mathrm{g} \text { d.m. })\end{array}$ & $\begin{array}{l}77.8 \pm 6.9 \\
79.2 \pm 7.1\end{array}$ & $\begin{array}{l}81.5 \pm 7.1 \\
75.5 \pm 5.4^{*}\end{array}$ & NS \\
\hline $\begin{array}{l}\text { Kidney } \mathrm{Cu} \\
(\mu \mathrm{g} / \mathrm{g} \text { d.m. })\end{array}$ & $\begin{array}{l}33.4 \pm 5.7 \\
36.8 \pm 5.3^{*}\end{array}$ & $\begin{array}{l}37.6 \pm 5.9 \\
32.8 \pm 4.5^{*}\end{array}$ & NS \\
\hline $\begin{array}{l}\text { Kidney Cr } \\
\text { ( } \mu \mathrm{g} / \mathrm{g} \text { d.m. })\end{array}$ & $\begin{array}{l}0.57 \pm 0.14 \\
0.84 \pm 0.12 *\end{array}$ & $\begin{array}{l}0.70 \pm 0.13 \\
0.70 \pm 0.14\end{array}$ & NS \\
\hline
\end{tabular}

Clodfelder et al. [37] reported that $\mathrm{Cr}_{3} \mathrm{O}\left(\mathrm{O}_{2} \mathrm{CCH}_{2} \mathrm{CH}_{3}\right)_{6}$ $\left.\left(\mathrm{H}_{2} \mathrm{O}\right)_{3}\right)^{+}$is absorbed with a very high efficiency of 40 $60 \%$, while popular $\mathrm{Cr}$ supplements such as $\mathrm{CrCl}_{3}, \mathrm{Cr}(\mathrm{III})$ nicotinate, or CrPic are absorbed at only $0.5-1.3 \%$ of the gavaged dose. The difference in the degree of absorption is readily explained by the stability and solubility of the cation in the physiological milieu. The detailed mechanisms of antidiabetic action of CrProp have not been fully elucidated.

The therapeutic properties of CrProp in relation to its anti-diabetic, insulin-sensitizing potential were discussed in other publications $[12,26,38]$ and will not be repeated in this article.

The importance of thiamine for the endocrine and exocrine function of pancreas $\beta$-cells was described in the 1970s and 1980s. Thiamine deficiency was shown to impair the insulin synthesis and secretion [40, 41]. On the other hand, a reduction of thiamine transport across the intestine has been reported in insulin deficiency states [18]. It has been suggested that thiamine deficiency may occur in diabetes [21]. However, to the authors knowledge there is no information whether insulin resistance and hyperinsulinemia can influence thiamine status.

In this study, rats fed the high-fructose diet developed insulin resistance and hyperinsulinemia, which did not affect erythrocytes transketolase activity. However, ETK is not a sensitive biomarker of thiamine status, thus acceleration of its activity by thiamine pyrophosphate (TPP) may give more accurate results. The enhancement of ETK activity (after adding TPP) indicates thiamine deficiency. Also other biomarkers of thiamine status (e.g., erythrocyte thiamine and its phosphorylated esters, urinary thiamine excretion [42]) should be measured to give more insight into the relationship between thiamine and insulin resistance.

However, the purpose of this study was not to search for this relationship, but rather to evaluate the therapeutic potential of supplementary thiamine (alone) and combined with CrProp.

In the literature there is some information concerning the therapeutic potential of thiamine and its analogue in hyperglycemic states. For example, Berrone et al. [43] showed that human umbilical vein endothelial cells and bovine retinal pericytes treated in vitro with thiamine and benfotiamine (a synthetic analogue of thiamine) reduced activation of the polyol pathway of glucose metabolism and increased transketolase expression in the presence of hyperglycemia.

In an animal (rat) model of insulin-deficient diabetes, Karachalias et al. [44] found that long-term (24 weeks) thiamine and benfotiamine supplementation decreased 
$\mathrm{HbA1C}$ and prevented an increased urinary excretion of protein glycation, oxidation, and nitration adducts, thus these agents reversed early-stage diabetic nephropathy. Gonzalez-Ortiz et al. in a pilot study [45] reported that drug-naïve type 2 diabetic patients administered $150 \mathrm{mg}$ of thiamine per day for 4 weeks had slightly decreased blood glucose and leptin concentrations. However, this intervention did not influence $\mathrm{HbA1C}$, blood lipids, or inflammation markers (IL-6, TNF- $\alpha$, and adiponectin).

In diabetic STZ-injected rats, high-dose thiamine $(70 \mathrm{mg} /$ $\mathrm{kg}$ of diet/day) given for 24 weeks decreased blood total cholesterol and triacylglycerol levels [16].

Both thiamine and $\mathrm{Cr}(\mathrm{III})$ compounds are considered as potential antioxidants. In the rat liver microsomes thiamine decreased lipid peroxidation due to a direct interaction with free radicals and hydroperoxides [46]. Also better absorbed lipid-soluble analogs of thiamine, i.e., benfotiamine, reduced oxidative stress in rat and porcine kidney cells as well as in rats and humans [47-50].

In this study, supplementary thiamine $(10 \mathrm{mg} / \mathrm{kg}$ body mass/day) showed a moderate antioxidant capacity, as it reduced serum TAS level by $13 \%$ in rats fed a highfructose diet.

In insulin resistance oxidative stress and increased inflammation usually occur, which induces the expression of specific cytokines. Tumor necrosis factor alpha, was the first proinflammatory cytokine found to induce insulin resistance $[51,52]$. Later such ability was confirmed also for other cytokines, such as IL-6, resistin, monocyte chemoattractant protein-1, angiotensinogen, visfatin, retinol-binding protein4 [53-56]. According to a hypothesis presented by Penntinen [57], an increased plasma IL-2 concentration brings about a reduction of bioavailability of insulin-like growth factor-1, by reducing the production of androgenic hormones, thus contributing to insulin resistance.

In this study, neither thiamine alone nor combined with CrProp affected serum TNF- $\alpha$ or IL-2 levels. Similarly, in a study by Gonzalez-Ortiz et al. [45] thiamine administration did not improve IL-6, TNF- $\alpha$, or adiponectin levels in drugnaïve diabetics.

Anti-inflammatory properties of $\mathrm{Cr}(\mathrm{III})$ compounds were examined by Jain and co-workers [58, 59]. The authors found that $\mathrm{Cr}$ (III) (administered in niacinate or dinicocysteinate) improved inflammatory status as determined by interleukin IL-6, TNF- $\alpha$, C-reactive protein, monocyte chemotactic protein-1, and intercellular adhesion molecule 1 (ICAM-1) in diabetic rats.

Supplementary minerals, including $\mathrm{Cr}$, can affect mineral status, due to possible interactions with other macro- and microelements at absorption, transport, metabolism, and other levels. For example, $\mathrm{Cr}$ (III) and $\mathrm{Fe}$ can compete for binding sites in transferrin. For this reason the question of $\mathrm{Cr}-\mathrm{Fe}$ interactions should be addressed whenever $\mathrm{Cr}(\mathrm{III})$ is to be administrated orally. In our previous study [12], it was shown that supplemental CrProp, given at dosages of $5 \mathrm{mg}$ $\mathrm{Cr} / \mathrm{kg}$ body mass/day for 8 weeks, decreased the kidney $\mathrm{Fe}$ concentration in rats. Also Clodfelder et al. [38] reported that supplementary CrProp (1 mg Cr kg/body mass/day, for 24 weeks) also decreased kidney Fe content in a rat model of early stage of type 2 diabetes. Dogukan et al. [60] observed that high-fat fed streptozotocin-injected rats supplemented with $\mathrm{Cr}(\mathrm{III})$ histidinate $(8.2 \%$ elemental $\mathrm{Cr})$ in dosages of $110 \mu \mathrm{g}$ CrHis $\mathrm{kg}$ body mass/day for 10 weeks had decreased liver and kidney $\mathrm{Cu}$ content with a parallel increase in $\mathrm{Zn}$ levels in both organs. Similar results were previously noticed in another study of this team with regard to young and pregnant rabbits [61].

The mechanism of thiamine-mineral interactions is unknown and the literature data is scant. Although in this study neither thiamine nor thiamine-Cr(III)Prop supplementation affected tissular zinc contents, in some studies such a relationship was mentioned. For example, Agte et al. [62] investigated the effect of water-soluble vitamins on in vitro zinc uptake in human erythrocytes in $\mathrm{Zn}$ deficiency, normal and excess conditions. It was found that in $\mathrm{Zn}$ deficiency an addition of thiamine to media enhanced $\mathrm{Zn}$ uptake, while under normal level and excess of zinc there was no interaction. On the other hand, thiamine enhanced zinc transport in a model of the small intestine (Caco-2 cells) only in a condition without oxidative stress [63]. However, these studies were performed under in vitro conditions, thus due to a lack of endocrine function they cannot mimic in vivo conditions.

Thiamine is a compound containing in its molecule four nitrogen atoms and one sulfur atom, thus it has some metalchelating potential. It was used in the treatment of metal $(\mathrm{Pb}$ and $\mathrm{Cd}$ ) poisoning [64-66]. For this reason we evaluated the effects of thiamine on tissular (liver and kidney) $\mathrm{Fe}, \mathrm{Zn}, \mathrm{Cu}$, and $\mathrm{Cr}$ levels in rats. It was shown that supplementary thiamine $(10 \mathrm{mg} / \mathrm{kg}$ body mass/day) increased liver $\mathrm{Cu}$ content (by $11 \%$ ), while it decreased kidney $\mathrm{Zn}$ and $\mathrm{Cu}$ levels (7-13\%) in high-fructose fed rats. However, these changes appear to be rather small, thus their significance for the overall mineral status is unclear.

In conclusion, the results of this study confirmed that both supplementary CrProp (1 mg/kg body mass/day) and thiamine $(10 \mathrm{mg} / \mathrm{kg}$ body mass/day) have comparable insulin-sensitizing and blood-lipid-lowering potential in rats.

Generally, the efficacy of CrProp action seems stronger than that of thiamine, since the dose of the latter applied in the experiment was tenfold higher, to produce similar effects in rats. However, no synergistic effects have been detected. Therefore there is no rationale to advocate the combined CrProp and thiamine supplementation for the prevention and treatment of insulin resistance. 
Conflict of interest statement The authors declare that there are no conflicts of interest.

Open Access This article is distributed under the terms of the Creative Commons Attribution License which permits any use, distribution, and reproduction in any medium, provided the original author(s) and the source are credited.

\section{References}

1. Smyth S, Heron A (2006) Diabetes and obesity: the twin epidemics. Nat Med 12(1):75-80

2. Koh-Banerjee P, Wang Y, Hu FB, Spiegelman D, Willett WC, Rimm EB (2004) Changes in body weight and body fat distribution as risk factors for clinical diabetes in US men. Am J Epidemiol 159:1150-1159

3. Muoio DM, Newgard CB (2008) Mechanisms of disease: molecular and metabolic mechanisms of insulin resistance and beta-cell failure in type 2 diabetes. Nat Rev Mol Cell Biol 9:193-205

4. Gillies CL, Abrams KR, Lambert PC, Cooper NJ, Sutton AJ, Hsu RT, Khunti K (2007) Pharmacological and lifestyle interventions to prevent or delay type 2 diabetes in people with impaired glucose tolerance: systematic review and meta-analysis. BMJ 334:299

5. Stallings D, Vincent JB (2006) Chromium. A case study in how not to perform nutritional research. Curr Topics Nutraceut Res 4:89-112

6. Hua Y, Clark S, Ren J, Sreejayan N (2012) Molecular mechanisms of chromium in alleviating insulin resistance. J Nutr Biochem 23 (4):313-319

7. Pei D, Hsieh CH, Hung YJ, Li JC, Lee CH, Kuo SW (2006) The influence of chromium chloride-containing milk to glycemic control of patients with type 2 diabetes mellitus: a randomized, double-blind, placebo-controlled trial. Metabolism 55:923-927

8. Racek J, Trefil L, Rajdl D, Mudrova V, Hunter D, Senft V (2006) Influence of chromium-enriched yeast on blood glucose and insulin variables, blood lipids, and markers of oxidative stress in subjects with type 2 diabetes mellitus. Biol Trace Elem Res 109:215-230

9. Sharma S, Prasad Agrawa R, Choudhary M, Jain S, Goya S, Agarwal V (2011) Beneficial effect of chromium supplementation on glucose, HbA1C and lipid variables in individuals with newly onset type-2 diabetes. J Trace Elem Med Biol 25:149-153

10. Gunton JE, Cheung NW, Hitchman R, Hams G, O'Sullivan C, Foster-Powell K, McElduff A (2005) Chromium supplementation does not improve glucose tolerance, insulin sensitivity, or lipid profile: a randomized, placebo-controlled, double-blind trial of supplementation in subjects with impaired glucose tolerance. Diabetes Care 28:712-713

11. Kleefstra N, Houweling S, Jansman FGA, Groenier KH, Gans ROB, Mayboom-de Jong B, Bakker SJ, Bilo HJ (2006) Chromium treatment has no effect in patients with poorly controlled, insulin-treated type 2 diabetes in an obese Western population: a randomized, double-blind, placebo-controlled trial. Diabetes Care 29:521-525

12. Król E, Krejpcio Z, Byks H, Bogdański P, Pupek-Musialik D (2011) Effects of chromium brewer's yeast supplementation on body mass, blood carbohydrates, and lipids and minerals in type 2 diabetic patients. Biol Trace Elem Res 143(2):726-737

13. DiBona KR, Love S, Rhodes NR, McAdory D, Sinha SH, Kern N, Kent J, Strickland J, Wilson A, Beaird J, Ramage J, Rasco JF, Vincent JB (2011) Chromium is not an essential trace element for mammals: effects of a "low-chromium" diet. J Biol Inorg Chem 16:381-390
14. Król E, Krejpcio Z (2011) Evaluation of anti-diabetic potential of chromium(III) propionate complex in high-fat diet fed and STZ injected rats. Food Chem Toxicol 49(12):3217-3223

15. Beltramo E, Berrone E, Tarallo S, Porta M (2008) Effects of thiamine and benfotiamine on intracellular glucose metabolism and relevance in the prevention of diabetic complications. Acta Diabetol 45(3):131-141

16. Babaei-Jadidi R, Karachalias N, Kupich C, Ahmed N, Thornalley PJ (2004) High-dose thiamine therapy counters dyslipidaemia in streptozotocin-induced diabetic rats. Diabetologia 47(12):2235-2246

17. La Selva M, Beltramo E, Pagnozzi F, Bena E, Molinatti PA, Molinatti GM, Porta M (1996) Thiamine corrects delayed replication and decreases production of lactate and advanced glycation end-products in bovine retinal and human umbilical vein endothelial cells cultured under high glucose conditions. Diabetologia 39 (11):1263-1268

18. Page GL, Laight D, Cummings MH (2011) Thiamine deficiency in diabetes mellitus and the impact of thiamine replacement on glucose metabolism and vascular disease. Int J Clin Pract 65(6):684-690

19. Thameem F, Wolford JK, Bogardus C, Prochazka M (2001) Analysis of SLC19A2, on 1q23.3 encoding a thiamine transporter as a candidate gene for type 2 diabetes mellitus in Pima Indians. Mol Genet Metab 72(4):360-363

20. Oishi K, Hofmann S, Diaz GA, Brown T, Manwani D, Ng L, Young R, Vlassara H, Ioannou YA, Forrest D, Gelb BD (2002) Targeted disruption of SLCA19A2, the gene encoding the highaffinity thiamin transporter Thtr-1, causes diabetes mellitus, sensorineural deafness and megaloblastosis in mice. Hum Mol Genet 11(23):2951-2960

21. Thornalley PJ, Babaei-Jadidi R, Al Ali H, Rabbani N, Antonysunil A, Larkin J, Ahmed A, Rayman G, Bodmer CW (2007) High prevalence of low plasma thiamine concentration in diabetes linked to a marker of vascular disease. Diabetologia 50(10):2164-2170

22. Kohda Y, Umeki M, Kono T, Terasaki F, Matsumura H, Tanaka T (2010) Thiamine ameliorates diabetes-induced inhibition of pyruvate dehydrogenase $(\mathrm{PDH})$ in rat heart mitochondria: investigating the discrepancy between PDH activity and PDH E1alpha phosphorylation in cardiac fibroblasts exposed to high glucose. J Pharmacol Sci 113(4):343-352

23. Pácal L, Tomandl J, Svojanovsky J, Krusová D, Stepánková S, Rehorová J, Olsovsky J, Belobrádková J, Tanhäuserová V, Tomandlová M, Muzík J, Kanková K (2011) Role of thiamine status and genetic variability in transketolase and other pentose phosphate cycle enzymes in the progression of diabetic nephropathy. Nephrol Dial Transplant 26(4):1229-1236

24. Rabbani N, Thornalley PJ (2011) Emerging role of thiamine therapy for prevention and treatment of early-stage diabetic nephropathy. Diabetes Obes Metab 13(7):577-583

25. Katare RG, Caporali A, Oikawa A, Meloni M, Emanueli C, Madeddu P (2010) Vitamin B1 analog benfotiamine prevents diabetes-induced diastolic dysfunction and heart failure through Akt/Pim-1-mediated survival pathway. Circ Heart Fail 3(2):294 305

26. Król E, Krejpcio Z (2010) Chromium(III) propionate complex supplementation improves carbohydrate metabolism in insulinresistance rat model. Food Chem Toxicol 48:2791-2796

27. Reeves PG, Nielsen FH, Fahey GC Jr (1993) AIN-93 purified diets for laboratory rodents: final report of the American Institute of Nutrition ad hoc writing committee on the reformulation of the AIN-76A rodent diet. J Nutr 123:1939-1951

28. Earnshaw A, Figgis BN, Lewis J (1966) Chemistry of polynuclear compounds Part VI. Magnetic properties of trimeric chromium and iron carboxylates. J Chem Soc A 1966:1656-1663

29. Albanese AA, Brin M (1967) Functional evaluation of nutritional status: thiamine. In: Albanese AA (ed) Newer methods of nutrition biochemistry. Academic, New York, pp 407-445 
30. Matthews DR, Hosker JP, Rudenski AS, Naylor BA, Treacher DF, Turner RC (1985) Homeostasis model assessment: insulin resistance and beta-cell function from fasting plasma glucose and insulin concentrations in man. Diabetologia 28:412-419

31. Cerulli J, Grabe DW, Gauthier I, Malone M, McGoldrick MD (1998) Chromium picolinate toxicity. Ann Pharmacother 32 (4):428-431

32. Stumvoll M, Gerich J (2001) Clinical features of insulin resistance and beta cell dysfunction and the relationship to type 2 diabetes. Clin Lab Med 21(1):31-51

33. Garaulet M, Madrid JA (2010) Chronobiological aspects of nutrition, metabolic syndrome and obesity. Adv Drug Deliv Rev 62:967-978

34. Harton A, Terrell K, Huffman JC, MacDonald C, Beatty A, Li S, O'Connor CJ, Vincent JB (1997) Synthesis and characterization of novel oxo-bridged dinuclear and hydroxo-bridged trinuclear chromium(III) assemblies. Inorg Chem 36:4875-4882

35. Clodfelder BJ, Chang C, Vincent JB (2004) Absorption of the biomimetic chromium cation triaqua-l-oxo-hexapropionatotrichromium(III) in rats. Biol Trace Elem Res 98:159-169

36. Sun Y, Clodfelder BJ, Shute AA, Irvin T, Vincent JB (2002) The biomimetic $\left[\mathrm{Cr}_{3} \mathrm{O}\left(\mathrm{O}_{2} \mathrm{CCH}_{2} \mathrm{CH}_{3}\right)_{6}\left(\mathrm{H}_{2} \mathrm{O}\right)_{3}\right]+$ decreases plasma insulin, cholesterol, and triglicerides in healthy and type II diabetic rats but not type I diabetic rats. J Biol Inorg Chem 7:852-862

37. Clodfelder BJ, Emamaullee J, Hepburn DD, Chakov NE, Nettles HS, Vincent JB (2001) The trail of chromium(III) in vivo from the blood to the urine: the roles of transferrin and chromodulin. J Biol Inorg Chem 6:608-617

38. Clodfelder BJ, Gullick BM, Lukaski HC, Neggers Y, Vincent JB (2005) Oral administration of the biomimetic $\left[\mathrm{Cr}_{3} \mathrm{O}\left(\mathrm{O}_{2} \mathrm{CCH}_{2} \mathrm{CH}_{3}\right)_{6}\left(\mathrm{H}_{2} \mathrm{O}\right)_{3}\right]+$ increases insulin sensitivity and improves blood plasma variables in healthy and type 2 diabetic rats. J Biol Inorg Chem 10:119-130

39. Clodfelder BJ, Vincent JB (2005) The time-dependent transport of chromium in adult rats from the bloodstream to the urine. J Biol Inorg Chem 10:383-393

40. Rathanaswami P, Pourany A, Sundaresan R (1991) Effects of thiamine deficiency on the secretion of insulin and the metabolism of glucose in isolated rat pancreatic islets. Biochem Int 25(3):577-583

41. Rathanaswami P, Sundaresan R (1991) Effects of thiamine deficiency on the biosynthesis of insulin in rats. Biochem Int 24 (6): 1057-1062

42. WHO/FAO (2004) Vitamin and mineral requirements in human nutrition, 2nd edn. World Health Organization, Geneva, 165-168

43. Berrone E, Beltramo E, Solimine C, Ape AU, Porta M (2006) Regulation of intracellular glucose and polyol pathway by thiamine and benfotiamine in vascular cells cultured in high glucose. $\mathrm{J}$ Biol Chem 281:9307-9313

44. Karachalias N, Babaei-Jadidi R, Rabbani N, Thornalley PJ (2010) Increased protein damage in renal glomeruli, retina, nerve, plasma and urine and its prevention by thiamine and benfotiamine therapy in a rat model of diabetes. Diabetologia 53(7):1506-1516

45. González-Ortiz M, Martínez-Abundis E, Robles-Cervantes JA, Ramírez-Ramírez V, Ramos-Zavala MG (2011) Effect of thiamine administration on metabolic profile, cytokines and inflammatory markers in drug-naïve patients with type 2 diabetes. Eur J Nutr 50 (2):145-149

46. Lukienko PI, Mel'nichenko NG, Zverinskii IV, Zabrodskaya SV (2000) Antioxidant properties of thiamine. Bull Exp Biol Med 130 (9):874-876

47. Schmid U, Stopper H, Heidland A, Schupp N (2008) Benfotiamine exhibits direct antioxidative capacity and prevents induction of DNA damage in vitro. Diabetes Metab Res Rev 24:371-377

48. Schupp N, Dette EM, Schmid U, Bahner U, Winkler M, Heidland A, Stopper H (2008) Benfotiamine reduces genomic damage in peripheral lymphocytes of hemodialysis patients. Naunyn Schmiedebergs Arch Pharmacol 378:283-291
49. Balakumar P, Chakkarwar VA, Singh M (2009) Ameliorative effect of combination of benfotiamine and fenofibrate in diabetes-induced vascular endothelial dysfunction and nephropathy in the rat. Mol Cell Biochem 320:149-162

50. Verma S, Reddy K, Balakumar P (2010) The defensive effect of benfotiamine in sodium arsenite-induced experimental vascular endothelial dysfunction. Biol Trace Elem Res 137:96-109

51. Feinstein R, Kanety H, Papa MZ, Lunenfeld B, Karasik A (1993) Tumor necrosis factor- $\alpha$ suppresses insulin-induced tyrosine phosphorylation of insulin receptor and its substrates. J Biol Chem 268:26055-26058

52. Hotamisligil GS, Shargill NS, Spiegelman BM (1993) Adipose expression of tumor necrosis factor- $\alpha$ : direct role in obesitylinked insulin resistance. Science 259:87-91

53. Zhang Y, Proenca R, Maffei M, Barone M, Leopold L, Friedman JM (1994) Positional cloning of the mouse obese gene and its human homologue. Nature 372:425-432

54. Fried SK, Bunkin DA, Greenberg AS (1998) Omental and subcutaneous adipose tissues of obese subjects release interleukin-6: depot difference and regulation by glucocorticoid. J Clin Endocrinol Metab 83:847-850

55. Steppan CM, Bailey ST, Bhat S, Brown EJ, Banerjee RR, Wright CM, Patel HR, Ahima RS, Lazar MA (2001) The hormone resistin links obesity to diabetes. Nature 409:307-312

56. Fukuhara A, Matsuda M, Nishizawa M, Segawa K, Tanaka M, Kishimoto K, Matsuki Y, Murakami M, Ichisaka T, Murakami H, Watanabe E, Takagi T, Akiyoshi M, Ohtsubo T, Kihara S, Yamashita S, Makishima M, Funahashi T, Yamanaka S, Hiramatsu R, Matsuzawa Y, Shimomura I (2005) Visfatin: a protein secreted by visceral fat that mimics the effects of insulin. Science 307:426-430

57. Penttinen J (1995) High plasma interleukin-2: a potential cause of insulin resistance. Med Hypothesis 45(6):614-616

58. Jain SK, Rains JL, Croad JL (2007) Effect of chromium niacinate and chromium picolinate supplementation on lipid peroxidation, TNF-alpha, IL-6, CRP, glycated hemoglobin, triglycerides, and cholesterol levels in blood of streptozotocin-treated diabetic rats. Free Radic Biol Med 43(8):1124-1131

59. Jain SK, Croad JL, Velusamy T, Rains JL, Bull R (2010) Chromium dinicocysteinate supplementation can lower blood glucose, CRP, MCP-1, ICAM-1, creatinine, apparently mediated by elevated blood vitamin $\mathrm{C}$ and adiponectin and inhibition of NFkappaB, Akt, and Glut-2 in livers of zucker diabetic fatty rats. Mol Nutr Food Res 54(9):1371-1380

60. Dogukan A, Sahin N, Tuzcu M, Juturu V, Orhan C, Onderci M, Komorowski J, Sahin K (2009) The effects of chromium histidinate on mineral status of serum and tissue in fat-fed and streptozotocintreated type II diabetic rats. Biol Trace Elem Res 131:124-132

61. Sahin K, Gülar T, Sahin N, Ertas ON, Erkal N (1999) The effect of chromium added into basal diet on serum total protein, urea, triglyceride, cholesterol and serum and tissue chromium, zinc, copper levels in rabbits. Tr J Vet Anim Sci 23:109-113

62. Agte VV, Nagmote RV, Tarwadi KV (2004) Comparative in vitro uptake of zinc by erythrocytes of normal vs Type 2 diabetic individuals and the associated factors. Diabetes Nutr Metab 17(6):343-349

63. Tupe RS, Agte VV (2010) Effect of water soluble vitamins on Zn transport of Caco-2 cells and their implications under oxidative stress conditions. Eur J Nutr 49(1):53-61

64. Tandon SK, Prasad S (2000) Effect of thiamine on the cadmiumchelating capacity of thiol compounds. Hum Exp Toxicol 19 (9):523-528

65. O'Hara TM, Bennett L, McCoy CP, Jack SW, Fleming S (1995) Lead poisoning and toxicokinetics in a heifer and fetus treated with $\mathrm{CaNa}_{2}$ EDTA and thiamine. J Vet Diagn Invest 7(4):531-537

66. Kim JS, Hamilton DL, Blakley BR, Rousseaux CG (1992) The effects of thiamin on lead metabolism: organ distribution of lead 203. Can J Vet Res 56(3):256-259 